\title{
Increasing the Impact of Industry-Academia Collaboration through Co-Production
}

\author{
Anna Sannö, Anna Ericson Öberg, Erik Flores-Garcia, and Mats Jackson
}

\author{
(6rom an academic perspective, it can be more interesting" \\ when things are not working than when they are. In \\ industry, we don't find that interesting, only frustrating. \\ Industrial manager in this study, \\ reflecting on university collaboration
}

\begin{abstract}
Increased competition and globalization motivate us to join forces to enhance the impact of the research conducted. Collaboration between organizations with different views can, however, be difficult to manage and needs awareness and skills to meet different expectations. This article will consider both a mutual industrial and academic perspective into the development of action research and, in six research project cases, empirically explore how the impact can be enhanced by considering certain key factors in the research process. How the phases of problem formulation, methodology, and results are managed is critical for the success of a collaboration and, thereby, its impact. Counter-productive forces that could dilute the progress over time need to be considered given that combining practical relevance and scientific rigour comes with challenges.
\end{abstract}

\section{Introduction}

Conducting research that is both practically relevant and scientifically rigorous, while also making a great societal impact, is a continuous challenge for scholars and universities (Bartunek \& Rynes, 2014; Coughlan et al., 2016; Ellström, 2008; Starkey \& Madan, 2001). In today's society, we live in a time with a high pace of changes leading to a constant need for new competences and skills. The mobility of scientific competences from universities to industrial firms enables firms to absorb and utilize the knowledge developed in academia (Kunttu et al., 2018). Increased competition and globalization in engineering communities are motivating industrial and academic institutions to improve their collaborations (Sandberg et al., 2011).

Embedded in the discussion of making societal impact is the character of knowledge, and this leads to realizing a new process for producing knowledge for change (Pettigrew, 2011). Several more practice-oriented methods have been developed over the years, such as action research (Coughlan \& Coghlan, 2002), collaboration research (Adler et al., 2004), collaborative management research (Coghlan et al., 2012), interactive research (Ellström, 2008; Svensson et al., 2007), cooperative inquiry
(Reason, 2006), and engaged research (Van de Ven, 2007). Nevertheless, collaboration is far from easy to manage, and scholars continue to address the question of how to involve practitioners. For example, boundaryspanning activities, such as appointing doctoral students, have been proposed (Kunttu et al., 2018). Further topics have been identified, such as exploring factors hindering collaboration (Kaymaz \& Eryiğit, 2011), reviewing success factors powering collaboration (Wohlin et al., 2012), and identifying where challenges may be found in the literature (Garousi et al., 2016). In such studies, however, it is typically the scholar's viewpoint that is considered (Kaymaz \& Eryiğit, 2011).

This article will, however, consider both a mutual industrial and academic perspective, and empirically explore how the impact can be enhanced by considering certain key factors in the research process. The context of the research conducted and presented in this article is in Sweden, where universities and international industrial companies are encouraged to conduct research together. The article highlights some of the major challenges when co-producing knowledge. Six research project cases will be presented and analyzed based on how different key factors are linked to the perceived impact of the projects. 


\title{
Increasing the Impact of Industry-Academia Collaboration through Co-Production
}

\author{
Anna Sannö, Anna Ericson Öberg, Erik Flores-Garcia, and Mats Jackson
}

The article is outlined as follows: after the introduction, the theoretical framework related to co-production and impact is presented, followed by a section on the research approach. Thereafter, the identified key factors and cases are presented. Further, the implications are discussed, concluding with how different elements and categories of impact relate to the management of the identified key factors.

\section{Background}

\section{Research positioning}

Before proceeding, we should clarify the epistemological assumptions that underlie our recommendations. This underlying assumption influences how we perceive the quality of research. We adopt the perspective that the purpose of management research is to generate knowledge that is valid as well as relevant from a practical standpoint inspired by Aguinis and Edwards (2014). The questions pursued by management research should draw from relevant theory and be anchored in issues relevant to the practice of management. Management research is here viewed as a scientific discipline that concerns methodological issues neighbouring on the social sciences, rooted in the complexity of change phenomena. It is not expected that management research will match the rigour and precision of research in the basic sciences. In applied science, the progress in management research depends rather on applying the best methods and is a continuous improvement of the methodological tools. In the theoretical framework, we will present how we have interpreted the important term of impact, starting with collaborative research.

\section{Collaborative research}

Collaboration with industry is critical for academia to create scientific knowledge and obtain industrial data. In turn, collaboration with universities is crucial for organizations in joint, scientific-based research projects in order to develop solutions for production-sourced problems (Kaymaz \& Eryiğit, 2011). When entering this kind of research project, the expectations of the contribution, not only to an academic audience but also to the organization where the problem exists, makes participatory research a suitable approach. The Knowledge Foundation in Sweden uses co-production as their way to adapt knowledge production to a more participatory way to conduct research. Co-production can be seen to exist when a research problem is framed in the context of the application and allows diffusion during knowledge production.
Coghlan and Coughlan (2008) identified three particular insights into collaborative research from their experience of designing, conducting, and publishing their collaborative research. In short, these are: 1) linking theory, practice, and collaboration; 2) capturing differences while sustaining collaboration; and 3) managing quality. This points towards more complex management when conducting the research, which is further discussed below. With the complexity arising from combining two differently organized systems, it is clear that multiple versions of collaboration exist, and these are dependent on too many factors to point towards one overall methodology. However, we have found Figure 1 to be a useful guide for us when discussing co-production.

The co-production process illustrated in Figure 1 has been developed from the Knowledge Foundation and further developed by the research group at Mälardalen University. First of all, trust and relations have to exist among the persons and organizations involved. The motivation to conduct co-creative research is triggered by the results and values that have been generated from earlier research or from people seeing the potential for new collaboration projects.

The conceptual co-creating model is based on three phases. It starts with formulating a common problem that both the academic and industrial representatives are interested in from their respective perspectives. The funding and resources phase is important in securing involvement and participation in the research from both industry and academia. Finally, in the collaborative work phase, the actual research needs to be conducted collaboratively, demanding relevant research methodologies and project management.

One of the goals of collaborative research is the generation of new knowledge that is of value to the participants, and to society at large. However, one challenge in working towards this goal is that practitioners and researchers develop a discrete understanding separately; each needs the other in the generation of a shared understanding. The fact that researchers investigate a topic important to practitioners does not necessarily mean that the researchers are to apprehend what that topic means to practitioners, and vice versa. Both parties work to different timescales, objectives, reward systems, and perceptions, and they understand each other's practice differently (Garousi et al., 2016). Each has to train and educate others both to think and to apply that thinking systematically and even creatively to the 


\section{Increasing the Impact of Industry-Academia Collaboration through Co-Production} Anna Sannö, Anna Ericson Öberg, Erik Flores-Garcia, and Mats Jackson

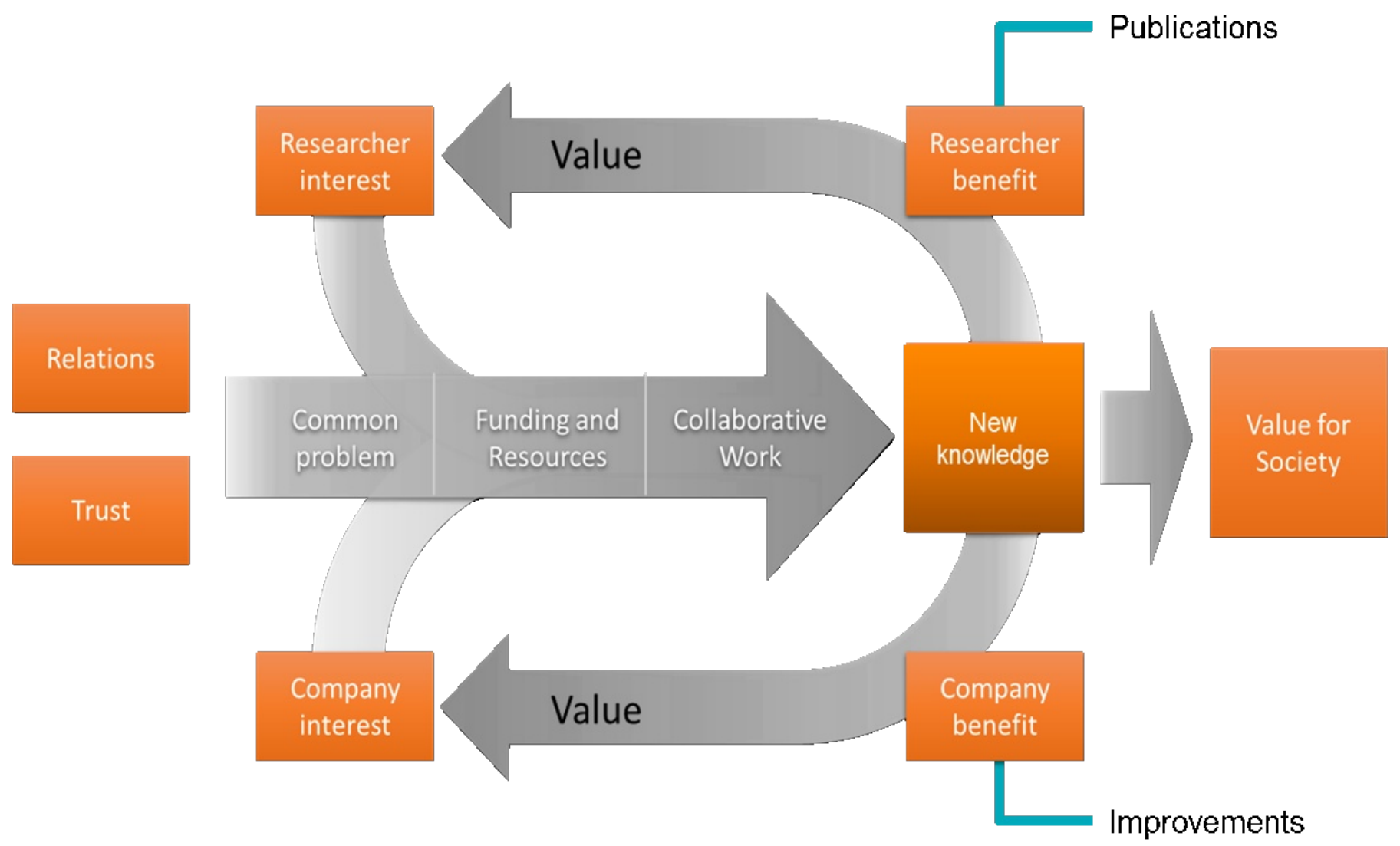

Figure 1. A Co-production process based on the Knowledge Foundation co-production model

design, running, and improvement of operations (Coughlan et al., 2016). A classical criticism towards collaborative research concerns the potential threats to "objectivity", and thereby also to the validity of the research results, due to the involvement of the researcher in practical activities. On the other hand, there are also counter-arguments that a collaborative relationship may contribute to better access to important processes, but also to more valid data compared with traditional research (Argyris, 1980). The process of co-creating research questions needs to expose the tensions in the process of learning to collaborate and to accommodate different perspectives of research partners (Shani et al., 2007). Scientific knowledge that does not make the required contribution seriously hinders university-industry collaboration. If the universities are not creating knowledge to solve industry problems, industry will have less regard for the knowledge provided by the universities (Kaymaz \& Eryiğit, 2011).

\section{Impact}

The concerns in the literature often come back to the terms of rigorous and relevant research. The research process itself should be transparent and carefully considered in order to create rigorous research. Its usefulness indicates the need for relevance and rather addresses the question of how we conduct relevant research. Some streams in research argue that the relevance should come from the gap of existing knowledge in research (Mohrman et al., 2001)

The rigour and relevance gaps are said to stem from the alienation of practitioners from formal academic styles and lead to substantial stylistic differences (Kelemen \& Bansal, 2002). This issue is related to knowledge transfer and interpretation, with the problem lying in the inability or unwillingness of academic researchers to translate their insights for practitioners (Chen et al., 2013). Further, Antonacopoulou (2009) argued that impact does matter in management scholarship, because it is a means of demonstrating the transformation of general information into meaningful knowledge enabling purposeful action. The impact matters because it demonstrates what can happen when research brings attention to neglected issues, it poses different questions, and it builds confidence to experiment. 


\title{
Increasing the Impact of Industry-Academia Collaboration through Co-Production
}

\author{
Anna Sannö, Anna Ericson Öberg, Erik Flores-Garcia, and Mats Jackson
}

Nor is the impact factor well-defined when conducting collaborative research, as the objective is more complex with more stakeholders aligned in the process. Meagher (2009) identified categories of impact, published by Pettigrew, 2011:

- Instrumental impacts: tangible products or services

- Conceptual impacts: scholarly contribution

- Capacity-building impacts: training and collaborative activities

- Cultural changes: achieved in the organizations

- Enduring connectivity impacts: knowledge exchange activities and relationships

According to Antonacopoulou (2009), one of the factors contributing to the tension between rigour and relevance of management scholarship relates to the questions we ask and the way we ask them. Learning to ask the "right" questions is fundamentally more important than a "right" answer. For management scholarship to be impactful, rigour and relevance must be connected so that the questions capture the interests and concerns of different users.

Antonacopoulou (2009) describes impact as having six elements (I-M-P-A-C-T):

I = Influential
(technical, scientific, and practical)
M = Memorable
(lasting experience, "measurable" outcome)
P = Practical
(integrating knowledge about the practitioner)
$\begin{aligned} & \text { A = Actionable } \\ & \text { (connections based on authenticity) }\end{aligned}$
$\begin{aligned} & \text { C = Co-created } \\ & \text { (through learning-driven collaborations) }\end{aligned}$
T = Transformational
(create new questions and possibilities)

Pettigrew (2001) has argued that the elements needed for the research to accomplish high impact and change are many, but the most frequently debated features include:
- a more porous boundary between science and society

- a resultant loss of research autonomy

- a breakdown of assumptions about unitary views of science

- greater range of participants and research practice

- greater recognition of the character of research practice and outcomes

- recognition of the complex interactions between multiple stakeholders in the research process and evaluation of the quality and relevance of research processes, outputs, and outcomes

The literature presented here is further related to the empirical data in the results and analysis described later in this article. The research approach is described in the next section.

\section{Research Approach}

The research projects described in this article have been conducted over five years in a co-production setting between universities and companies in Sweden. The participating companies are global companies within the automotive and pharmaceutical industry segment. The cases were selected based on companies who developed synergy projects with the universities in the past. Therefore, they also had an equal voice in terms of expecting research resulting in impact for them, too. They were interested in further collaboration with universities, which made it relevant to them to discuss the impact of the research. The purpose of this analysis is to capture important factors influencing the research process enabling enhanced impact.

While conducting co-production research, the authors identified certain key factors and challenges. Two of the authors were externally-employed doctoral students at the Innofacture Research School at Mälardalen University in Sweden. At the manufacturing company, a department with 10 researchers was established for manufacturing research with strategic and long-term academic partnership. Two of the authors managed the department, and two other universities had $\mathrm{PhD}$ students in the department. The steps leading to the results in this article are described in Table 1 and are inspired by Kolb's learning cycle (Kolb, 2014). 


\title{
Increasing the Impact of Industry-Academia Collaboration through Co-Production
}

\author{
Anna Sannö, Anna Ericson Öberg, Erik Flores-Garcia, and Mats Jackson
}

Table 1. The steps leading to the identified challenges, key factors, and analysis of impact in this study

\begin{tabular}{lll}
\hline Steps & Method & Participants \\
\hline Data collection & $\begin{array}{l}\text { Concrete experience by planning and } \\
\text { conducting co-creative research through } \\
\text { case studies, interactive research, and } \\
\text { participatory research approaches }\end{array}$ & $\begin{array}{l}\text { Three senior researchers; } \\
\text { seven active PhD students }\end{array}$ \\
\hline Reflective observation & Workshop, documentation, and analysis & $\begin{array}{l}\text { Three senior researchers; } \\
\text { seven active PhD students }\end{array}$ \\
\hline Abstract conceptualization & $\begin{array}{l}\text { Analyzing and concluding experiences, } \\
\text { capturing the findings in a practical } \\
\text { handbook (Sannö et al., 2018) }\end{array}$ & $\begin{array}{l}\text { Review from 30 industrial } \\
\text { managers and academic } \\
\text { researchers }\end{array}$ \\
\hline Active experimentation & $\begin{array}{l}\text { Analysis of impact and retrospectively } \\
\text { describing specific cases }\end{array}$ & Three former PhD students \\
\hline
\end{tabular}

The factors are summarized in Table 2 and Table 3 . The projects had been carried out in close collaboration with academia and industry, and all were related to technology management and innovation. The cases were selected on the basis that they all resulted in new knowledge for the researchers and the organizations.

\section{Co-Production in Industrial Cases}

Key factors related to perspectives from the co-production process

The different perspectives of the co-production research process, as described in the practical handbook (Sannö et al., 2018), are briefly described in Table 2. These process perspectives are further used to describe the six cases in the next section.

\section{The key factors as counterproductive forces influencing} the projects

Details of the identified counterproductive forces are presented in Table 3 (Sannö et al., 2018). These counterproductive forces are later used to further describe six cases.

\section{Case description and key factors related to impact}

The cases individually described below are analyzed from the literature in the impact section (Antonacopoulou, 2009; Meagher, 2009). The cases are then consolidated in the section that follows.

- Case A - "Disagreement on deliverables": This project studied variation when creating welding procedures; one university and four companies participated. The project management was run by a consultant who was hired by the university. However, during the early phases, the expectations of the project were never discussed. When publications were discussed after two years, the expectations of the participants differed, leading to mistrust. The result became useful for the industrial partners in capacity-building impacts but it also resulted in two publications written by the company. The lesson learned was the importance of gaining an understanding of what the respective participants want to get from the project, in line with driving forces and rewards, since it influences, for example, methodology and prioritization. Unfortunately, relations were broken and research in the same constellation did not happen again. The industrial company managed to produce actionable results and raised new questions with other partners.

- Case B - "Manufacturing of new product": This subproject was an externally-employed doctoral student project that investigated how to manufacture a new type of highly innovative product. The externally-employed doctoral student and the participants were employed at the company involved in the project. In the main project, other parties were also involved. Early on, the researchers in the project communicated effectively and received positive attention from the top management, competitors, as well as the media. The methodology was described in the research proposal and the result became useful for the company with instrumental impacts (products and services taken up by the company) as well as capacity-building impacts with training (sessions), and sustainable relationships. 


\title{
Increasing the Impact of Industry-Academia Collaboration through Co-Production
}

\author{
Anna Sannö, Anna Ericson Öberg, Erik Flores-Garcia, and Mats Jackson
}

Table 2. The different perspectives in the research process that were identified as key factors to manage

\begin{tabular}{|c|c|c|c|}
\hline & Definition & Industrial Perspective & Academic Perspective \\
\hline \multirow[t]{2}{*}{$\begin{array}{l}\text { Problem } \\
\text { formulation }\end{array}$} & $\begin{array}{l}\text { Stakeholders identify a } \\
\text { knowledge gap to fill. }\end{array}$ & $\begin{array}{l}\text { Often desired to solve a current problem } \\
\text { that is explicit and identified by the } \\
\text { organization. }\end{array}$ & \multirow[t]{2}{*}{$\begin{array}{l}\text { Find a research gap based on previous } \\
\text { knowledge. Whether it works in } \\
\text { practice or not is not the primary goal, } \\
\text { but knowing why is. }\end{array}$} \\
\hline & & $\begin{array}{l}\text { Short-term problems are often easier to } \\
\text { prioritize. }\end{array}$ & \\
\hline Methodology & $\begin{array}{l}\text { The fundamental } \\
\text { strategy that outlines } \\
\text { the research as well as } \\
\text { methods to collect and } \\
\text { analyze the data. }\end{array}$ & $\begin{array}{l}\text { To solve problems using organizationally } \\
\text { experience, best practice, or traditional } \\
\text { methods. }\end{array}$ & $\begin{array}{l}\text { Key features to legitimize and describe } \\
\text { how the researcher has arrived at the } \\
\text { result to critically review the research } \\
\text { process. Research ethics are also } \\
\text { fundamental. }\end{array}$ \\
\hline Result & $\begin{array}{l}\text { The expected and } \\
\text { realized outcome of } \\
\text { the project. }\end{array}$ & $\begin{array}{l}\text { A solution to an existing problem and } \\
\text { preferably possible to demonstrate. } \\
\text { Newness of less importance compared to } \\
\text { the effect and ease of implementation. }\end{array}$ & $\begin{array}{l}\text { Contribute to the educational system } \\
\text { by providing and adding new } \\
\text { knowledge by publishing, and training } \\
\text { students. }\end{array}$ \\
\hline
\end{tabular}

Several publications such as conceptual impacts with unique material "from inside" an organization also had high academic value and interest. The project became influential, memorable, practical, actionable, cocreated, and transformational (i.e., it had I-M-P-A-C-T, as described earlier), with new questions leading to new research projects.

- Case C - "Development of a new production system": This project developed a production system where five different families of powertrains for the automotive industry could be assembled in one line. The company co-employed academic staff. The academic researchers formulated the aim of the project as a practical need. The academics also announced that, in addition to this, their objective was to collect material for scientific publications and hold presentations, seminars, or workshops to disseminate knowledge on the use of simulation technique in the organization. One of the success factors was that the time plan was based on estimates from previous projects, which did not involve changes of equal magnitude to the production processes. The project involved the externally-employed participants in a number of joint activities during the course of the project, with high attendance because of the good formulation of the practical needs, and tangible products and services. The project led to the implementation of the new production system. Access to data enabled joint learning and conceptual impact with robust evidence-based data achieved from a research point of view as well, fulfilling the influential, memorable, practical, actionable, co-created, and transformational objectives. This conceptual knowledge also led to further research questions and projects.

- Case D - "Simulation in the development of production systems": This project aimed at acquiring knowledge about simulation for the development of production systems, including challenges and benefits. Researchers presented past and ongoing simulation-related projects to members of the manufacturing organization at university premises and at different manufacturing sites as well as workshop series developed on the topics. Company representatives and graduate students identified areas and evaluated the consequences of solutions through simulation. A similar approach was taken initially as in case C. The only difference was that the organization and academic institution did not know each other at the start of co-production. Cases given to academic partners were initially small in scope and involved decisions that had already been taken. Therefore, it took time and several joint activities before the participants of the project became aligned to expectations of knowledge. Cases to base this knowledge on were presented as examples, and practical solutions were important, but in the end, the expectations that emerged from the industry side went beyond solving an immediate issue. After building trust and relations, the project started to deliver rigorous data as well and co-created learning, leading to capacity-building impacts and further connectivity impacts. 


\section{Increasing the Impact of Industry-Academia Collaboration through Co-Production} Anna Sannö, Anna Ericson Öberg, Erik Flores-Garcia, and Mats Jackson

Table 3. Counterproductive forces from an academic and industrial perspective

\begin{tabular}{|c|c|c|c|}
\hline Key Factors & Definition & Industrial Perspective & Academic Perspective \\
\hline Reflections of time & $\begin{array}{l}\text { Not only measurable } \\
\text { but a perception that } \\
\text { can be different and } \\
\text { dependent on the } \\
\text { person. }\end{array}$ & $\begin{array}{l}\text { - Aiming at time reduction in } \\
\text { production or the } \\
\text { development process. } \\
\text { - Often a short-term focus. } \\
\text { - Time for reflection is often } \\
\text { rare. }\end{array}$ & $\begin{array}{l}\text { - Enabler for reflection connected to } \\
\text { building knowledge. } \\
\text { - Learning and understanding is a non- } \\
\text { linear process; they need to develop over } \\
\text { time. } \\
\text { - The publications system has a long-term } \\
\text { perspective; it might take years to publish. }\end{array}$ \\
\hline View on knowledge & $\begin{array}{l}\text { Many definitions } \\
\text { (e.g., context- } \\
\text { specific, relational, } \\
\text { tacit, explicit, or as a } \\
\text { process). }\end{array}$ & $\begin{array}{l}\text { - Diffuse term, often related to } \\
\text { the degree of education, } \\
\text { assignment, experience, or } \\
\text { years in the company. } \\
\text { - Competitive advantage; } \\
\text { included in their systems. }\end{array}$ & $\begin{array}{l}\text { - The core (the criterion) is to add new } \\
\text { knowledge by building new theory, } \\
\text { expanding, qualifying, reporting, or } \\
\text { testing existing theory. }\end{array}$ \\
\hline $\begin{array}{l}\text { Driving forces and } \\
\text { rewards }\end{array}$ & $\begin{array}{l}\text { Motivation for the } \\
\text { participants; what } \\
\text { you get } \\
\text { acknowledged for. }\end{array}$ & $\begin{array}{l}\text { - Mainly connected to a } \\
\text { problem; if related to } \\
\text { financial importance often } \\
\text { more prioritized, indicator } \\
\text { focused. } \\
\text { - Influenced by the culture. }\end{array}$ & $\begin{array}{l}\text { - Ability to identify a relevant problem, to } \\
\text { get funding, to conduct the research and } \\
\text { explicitly express your contribution in a } \\
\text { scientific way. } \\
\text { - Striving for publication in highly ranked } \\
\text { journals. }\end{array}$ \\
\hline Power dynamics & $\begin{array}{l}\text { Organizational as } \\
\text { well the perceived } \\
\text { differences in power } \\
\text { between people. }\end{array}$ & $\begin{array}{l}\text { - Often multiple career paths } \\
\text { - The position and title can be } \\
\text { the initial viewpoint, but } \\
\text { behind is rather personality, } \\
\text { previous achievements, ideas, } \\
\text { and experience. }\end{array}$ & $\begin{array}{l}\text { - Fewer career paths. } \\
\text { - Hierarchy is clearer. } \\
\text { - The titles are important because they } \\
\text { signal the level of achievement in } \\
\text { contributing to knowledge. }\end{array}$ \\
\hline Communication & $\begin{array}{l}\text { The exchange of } \\
\text { information by } \\
\text { speaking, writing, or } \\
\text { using other media to } \\
\text { communicate. }\end{array}$ & $\begin{array}{l}\text { - Important to understand the } \\
\text { local, cultural language (e.g., } \\
\text { the loudest voice is the only } \\
\text { voice heard or first speaker } \\
\text { advantage). } \\
\text { - Influences how to act, dress, } \\
\text { and behave. }\end{array}$ & $\begin{array}{l}\text { - Terminology is important; using } \\
\text { definitions. } \\
\text { - Argumentation is important to show the } \\
\text { value of the research; how and why you } \\
\text { have arrived at your findings. } \\
\text { - Ability to write and to publish is } \\
\text { important. }\end{array}$ \\
\hline
\end{tabular}




\title{
Increasing the Impact of Industry-Academia Collaboration through Co-Production
}

\author{
Anna Sannö, Anna Ericson Öberg, Erik Flores-Garcia, and Mats Jackson
}

- Case E - "Technology change with insights": This case was initiated as a project to upgrade a technology to improve the environmental impact of a process in a manufacturing plant. The team consisted of the researcher employed by the organization, a researcher from a university observing the other researcher, as well as the company team and suppliers. The researcher used visualization to communicate the role of the researcher and, early on, discussion concerning the methodology. The expectations of the technical support were at first higher than those of the management research. After implementing the technology, with several issues along the way, the organization realized that the need for knowledge had to be built upon their own competence, not by the knowledge of external parties. The co-production initiated a learning process inside the organization by asking research-related questions and by giving support to find solutions in the literature. The researcher built up knowledge about how different factors in the organization influenced the project while the participants learned how to manage the change process. It also led to mutual understanding of problems and how to develop a collaborative methodology to enhance learning in the organization. The project was influential, memorable as "before and after" memory, practical, actionable, co-created, and transformational, leading to several new questions and possibilities. Its conceptual impact was the scholarly contribution of innovation theory related to time and contexts, cultural change and enduring connectivity impacts, as well as capacity-building impacts of learning.

- Case F- "Study of re-used material with project cooperation issues": An evaluation was made concerning whether parts could be re-used, leading to a new technology to be used in the value chain. Several actors from different companies and universities joined the project, with the research leader acting as project manager. The project was sold to the companies as a practical problem where all the different perspectives were also taken into account. However, the driving forces of business interests by partners in the project misdirected the purpose and the methodology. The expected result was not achieved. The main finding was that a common problem formulation was missing and a failure to make sure, by communication and management, that all the actors were aligned through the process. In order to have done so, it would have been necessary to realize the driving forces and motivation for the project and what to expect from the actors. The project was hardly influential; it became less practical or academically rigorous and did not lead to further projects.

\section{Discussion}

Effective management of the phases of problem formulation, methodology, and results is important for successful collaboration and thereby impact. From the different cases, we can conclude that, even if there is not one methodology or research process, these phases are still important to clarify and manage when initiating a collaborative research project. The research should not be based on the interest of only one of the stakeholders; communication and mutual interest in a driving force are important key factors during all stages, opening up a more porous boundary between science and society (Pettigrew, 2011).

The summary of the cases presented in Table 4 shows the identified factors that influence the impact/implications of co-produced research. If we were to grade the perspectives by importance, we would see that the driving forces that motivate engagement in a project as well as communication are particularly important in terms of achieving impact, which is in accordance with previous findings (Garousi et al., 2016; Kaymaz \& Eryiğit, 2011; Sandberg et al., 2011). The cases were evaluated from the perspective of the different factors. Each case was assigned a grading for each factor according to the I-M-P-A-C-T elements described by Antonacopoulou (2009):

+ Several elements with a positive impact

$+\quad$ A few elements with a slightly positive impact

- A few elements with a slightly negative impact

-- Several elements with a negative impact

Further, the different categories of impact (Meagher, 2009) for each case were evaluated by the academic and industrial perception of the outcome.

\section{Positive impact

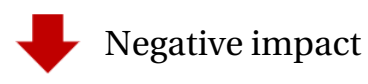

Just as Coghlan and Coughlan (2008) highlighted the insights of linking theory, practice, and collaboration, differences were encountered while sustaining the collaboration by managing the counterproductive forces. Built on trust and relationships, progress is facilitated and can lead to several impacts, as seen in the difference between Case C and Case D. If trust and relationships are built, the practical and scholarly results are 


\section{Increasing the Impact of Industry-Academia Collaboration through Co-Production}

Anna Sannö, Anna Ericson Öberg, Erik Flores-Garcia, and Mats Jackson

Table 4. Categories of impact and influence by the identified key factors for each case

\begin{tabular}{|c|c|c|c|c|c|c|}
\hline \multirow[b]{2}{*}{ Key Factor/Category of Impact } & \multicolumn{6}{|c|}{ Case } \\
\hline & $\mathbf{A}$ & $\mathbf{B}$ & $\mathbf{C}$ & $\mathbf{D}$ & $\mathbf{E}$ & $\mathbf{F}$ \\
\hline Problem formulation & ++ & ++ & ++ & ++ & + & - \\
\hline Methodology & - & ++ & ++ & ++ & ++ & - \\
\hline Result & -- & ++ & ++ & ++ & + & -- \\
\hline Reflections of time & - & - & + & + & + & -- \\
\hline View of knowledge & -- & ++ & - & ++ & + & -- \\
\hline Driving forces and rewards & -- & ++ & ++ & ++ & + & - \\
\hline Power dynamics & - & + & ++ & + & ++ & - \\
\hline Communication & - & ++ & ++ & ++ & + & -- \\
\hline Instrumental impacts & & & & & & \\
\hline Conceptual impacts & & & & & & \\
\hline Capacity-building impacts & & & & & & \\
\hline Cultural change & & & & & & \\
\hline Enduring connectivity impacts & & & & & & \\
\hline
\end{tabular}

likely to be equally balanced. A greater range of participants in the knowledge development process will require adaptation of the methodology (Pettigrew, 2011), and this will lead to cultural changes in both systems.

One limitation of the cases investigated is whether research funding was secured, because the driving force of obtaining funding will likely impact the project. We see the result of decades of emphasis on the co-production of knowledge in Sweden, but the study is limited to doctoral students in this environment and the international industrial companies involved. This article does not look toward theory development, nor method development, but rather creates a voice of experiences of scholars aiming for practical relevance in the academic system. We encourage the inclusion of other stakeholders from companies and academia to reflect on the characteristics and challenges addressed.

Today, several terms and definitions of quality and impact exist, but it is still difficult for academics to agree on these definitions and improve collaboration. Therefore, it is necessary to have tools, measurements, and methods to evaluate co-production and the impact it gives. We would like to emphasize the need for involving the participant stakeholders in the discussion. We therefore propose that greater emphasis should be placed on the Implications for Practice section (Bartunek \& Rynes, 


\title{
Increasing the Impact of Industry-Academia Collaboration through Co-Production
}

\author{
Anna Sannö, Anna Ericson Öberg, Erik Flores-Garcia, and Mats Jackson
}

2014), but also greater emphasis should be placed in the introduction and methodology parts of the resulting journal publications. By using the findings from this article, these can more explicitly be discussed by the collaborating organizations. As Adler and Harzing (2009) wrote, presenting research findings as if other researchers are the only end users is hardly an ideal situation for addressing complex questions in a way that contributes to society.

\section{Conclusion}

To do collaborative research requires awareness and certain skills from the participating organizations. In this article, we have used different forms of action research, and from the different industry-academic collaborations we have identified key factors influencing different elements - and categories of impact. We are contributing to the continuous discussion by scholars by including the academic and industrial views, seen as fundamental to fully realizing the research impact potential. How we manage the phases of problem formulation, methodology, and results is critical for successful collaboration and thereby its impact. Counter-productive forces that could dilute the progress also need to be considered since combining practical relevance and scientific rigour comes with challenges. A research gap concerning how to assess co-production was identified and further research on assessment models including impact needs to be conducted.
Citation: Sannö, A., Ericson Öberg, A., Flores-Garcia, E.,

\& Jackson., M.. 2019. Increasing the Impact of

Industry-Academia Collaboration through Co-

Production. Technology Innovation Management Review,

9(4): 37-47. http://doi.org/10.22215/timreview/1232

Keywords: action research, industry-academia collaboration, co-production, impact, collaboration, rigour, relevance, key factors

\section{About the Authors}

Anna Sannö is the Research Strategy Manager at Volvo CE, previously working as a Senior Lecturer in External Collaboration at Örebro University in Sweden. Her research focus is on sustainable operations management. Anna received her PhD in Innovation and Design from Mälardalen University where she belonged to the research school Innofacture. Anna has an industrial background in surface treatment and the automotive industry. She holds a BSc in Chemical Engineering from Chalmers University of Technology in Gothenburg, Sweden.

Anna Ericson Öberg is the Management System and Data Analysis Director at Volvo Construction Equipment and has been working with production, welding, and management since 2004. She has a PhD in Manufacturing Technology from Chalmers University of Technology in Gothenburg, Sweden. Her research interest lies in manufacturing improvements in the intersection between the research areas of quality, welding, and production and is managing and participating in several research projects. Anna holds an MSc in Manufacturing Management from Loughborough University in England and is Six Sigma Black Belt certified.

Erik Flores-Garcia is a doctoral student at Mälardalen University, Sweden. His research interests include discrete event simulation and decision-making. He holds an MSc in Production and Logistics from Mälardalen University and a BSc in Mechatronics from the Monterrey Institute of Technology and Higher Education in Mexico.

Mats Jackson is Professor of Innovative Production at Jönköping University, Sweden and is the Programme Manager of SPARK, their research and education environment focusing on knowledge-intensive product realization. He was previously the Professor of Innovation and Product Realisation at Mälardalen University in Sweden and the Manufacturing Research Manager at Volvo Construction Equipment. $\mathrm{He}$ was also the Project Manager for the research school Innofacture at Mälardalen University. He received his $\mathrm{PhD}$ in 2000 in Production System Development at Linköping University and has a background as a production engineer and management consultant in industry. 


\section{Increasing the Impact of Industry-Academia Collaboration through Co-Production}

\section{Anna Sannö, Anna Ericson Öberg, Erik Flores-Garcia, and Mats Jackson}

\section{References}

Adler, N., Shani, A. R., \& Styhre, A. 2004. Collaborative Research in Organizations: Foundations for Learning, Change, and Theoretical Development. Thousand Oaks, CA: Sage Publications.

Adler, N. J., \& Harzing, A.-W. 2009. When Knowledge Wins: Transcending the Sense and Nonsense of Academic Rankings. Academy of Management Learning \& Education, 8(1): 72-95. http://doi.org./10.5465/amle.2009.37012181

Aguinis, H., \& Edwards, J. R. 2014. Methodological Wishes for the Next Decade and How to Make Wishes Come True. Journal of Management Studies, 51(1): 143-174. http://doi.org/10.1111/joms.12058

Antonacopoulou, E. P. 2009. Impact and Scholarship: Unlearning and Practising to Co-Create Actionable Knowledge. Management Learning, 40(4): 421-430. http://doi.org/10.1177/1350507609336708

Argyris, C. 1980. Inner Contradictions of Rigorous Research. New York, NY: Academic Press.

Bartunek, J. M., \& Rynes, S. L. 2014. Academics and Practitioners Are Alike and Unlike:The Paradoxes of Academic-Practitioner Relationships. Journal of Management, 40(5): 1181-1201. http://doi.org/10.1177/0149206314529160

Chen, C. Y., Jim Wu, Y. C., \& Wu, W. H. 2013. A Sustainable Collaborative Research Dialogue between Practitioners and Academics. Management Decision, 51(3): 566-593. http://doi.org/10.1108/00251741311309661

Coghlan, D., Cirella, S., \& Shani, A. 2012. Action Research and Collaborative Management Research: More Than Meets the Eye? International Journal of Action Research, 8(1): 45-67. http://doi.org/10.1688/1861-9916_IJAR_2012_01_Shani

Coghlan, D., \& Coughlan, P. 2008. Action Learning and Action Research (ALAR): A Methodological Integration in an InterOrganizational Setting. Systemic Practice and Action Research, 21(2): 97-104.

http://doi.org/10.1007/s11213-007-9086-0

Coughlan, P., \& Coghlan, D. 2002. Action Research for Operations Management. International. Journal of Operations \& Production Management, 22(2): 220-240.

https://doi.org/10.1108/01443570210417515

Coughlan, P., Draaijer, D., Godsell, J., \& Boer, H. 2016. Operations and Supply Chain Management: The Role of Academics and Practitioners in the Development of Research and Practice. International Journal of Operations \& Production Management, 36(12): 1673-1695.

http://doi.org/10.1108/IJOPM-11-2015-0721

Ellström, P.-E. 2008. Knowledge Creation through Interactive Research: A Learning Approach. Paper presented at the Proceedings of the ECER Conference, September 8-12, 2008, University of Göteburg, Sweden.

Garousi, V., Petersen, K., \& Ozkan, B. 2016. Challenges and Best Practices in Industry-Academia Collaborations in Software Engineering: A Systematic Literature Review. Information and Software Technology, 79: 106-127. https://doi.org/10.1016/j.infsof.2016.07.006
Kaymaz, K., \& Eryiğit, K. Y. 2011. Determining Factors Hindering University-Industry Collaboration: An Analysis from the Perspective of Academicians in the Context of Entrepreneurial Science Paradigm. International Journal of Social Inquiry, 4(1).

Kelemen, M., \& Bansal, P. 2002. The Conventions of Management Research and Their Relevance to Management Practice. British Journal of Management, 13(2): 97-108. http://doi.org/10.1111/1467-8551.00225

Kolb, D. A. 2014. Experiential Learning: Experience as the Source of Learning and Development. Indianapolis, IN: Pearson.

Kunttu, L., Huttu, E., \& Neuvo, Y. 2018. How Doctoral Students and Graduates Can Facilitate Boundary Spanning between Academia and Industry. Technology Innovation Management Review, 8(6): 48-49.

http://doi.org/10.22215/timreview/1164

Meagher, L. 2009. Impact Evaluation of the Paccit Programme. Swindon, UK: Economic and Social Research Council.

Mohrman, S. A., Gibson, C. B., \& Allan M. Mohrman, J. 2001. Doing Research That Is Useful to Practice a Model and Empirical Exploration. Academy of Management Journal, 44(2): 357-375. http://doi.org/10.5465/3069461

Pettigrew, A. M. 2001. Management Research after Modernism. British Journal of Management, 12(1): 61-70. http://doi.org/10.1111/1467-8551.12.s1.8

Pettigrew, A. M. 2011. Scholarship with Impact. British Journal of Management, 22(3): 347-354. http://doi.org/10.1111/j.1467-8551.2011.00769.x

Reason, P. 2006. Choice and Quality in Action Research Practice. Journal of Management Inquiry, 15(2): 187-203. https://doi.org/10.1177\%2F1056492606288074

Sandberg, A., Pareto, L., \& Arts, T. 2011. Agile Collaborative Research: Action Principles for Industry-Academia Collaboration. IEEE Software, 28(4): 74-83. http://doi.org/10.1109/MS.2011.49

Sannö, A., Ericson Öberg, A., \& Jackson, M. 2018. How to Succeed with Co-Production: Experiences from Industrial Researchers. Eskilstuna, Sweden: Mälardalen University.

Shani, A. B., Mohrman, S. A., Pasmore, W. A., Stymne, B., \& Adler, N. (Eds.) 2007. Handbook of Collaborative Management Research. London: SAGE Publications.

Starkey, K., \& Madan, P. 2001. Bridging the Relevance Gap: Aligning Stakeholders in the Future of Management Research. British Journal of Management, 12(1): 3-26. http://doi.org/10.1111/1467-8551.12.s1.2

Svensson, L., Ellström, P.-E., \& Brulin, G. 2007. Introduction - On Interactive Research. International Journal of Action Research, 3(3): 233-249.

Van de Ven, A. H. 2007. Engaged Scholarship: A Guide for Organizational and Social Research. Oxford, UK: Oxford University Press.

Wohlin, C., Aurum, A., Angelis, L., Phillips, L., Dittrich, Y., Gorschek, T., Grahn, H., Henningsson, K., Kagstrom, S., Low, G., Rovegard, P., Tomaszewski, P., van Toorn, C., \& Winter, J. 2012. The Success Factors Powering Industry-Academia Collaboration. IEEE Software, 29(2): 67-73.

http://doi.org/10.1109/MS.2011.92 


\section{TIm Technology Innovation Management Review}

\section{Academic Affiliations and Funding Acknowledgements}
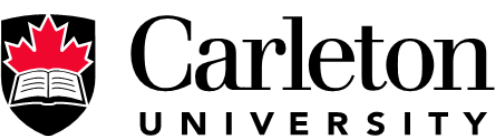

U N I V E R S I T Y

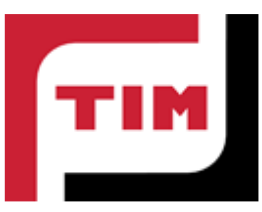

Technology Innovation Management (TIM; timprogram.ca) is an international master's level program at Carleton University in Ottawa, Canada. It leads to a Master of Applied Science (M.A.Sc.) degree, a Master of Engineering (M.Eng.) degree, or a Master of Entrepreneurship (M.Ent.) degree. The objective of this program is to train aspiring entrepreneurs on creating wealth at the early stages of company or opportunity lifecycles.

- The TIM Review is published in association with and receives partial funding from the TIM program. 